\title{
PERSPEKTIF CAREGIVER DALAM MERAWAT KELUARGA DENGAN OBESITAS: STUDI FENOMENOLOGI
}

\author{
Rohayati $^{*}$; Wiwin Wiarsih' ${ }^{2}$; Astuti Yuni Nursasi ${ }^{3}$ \\ 1. Program Studi S1Keperawatan, STIKes Mitra Keluarga, Bekasi-Indonesia \\ 2. Program Studi Magister Ilmu Keperawatan, FIK Universitas Indonesia, Depok-Indonesia \\ 3. Program Studi Magister Ilmu Keperawatan, FIK Universitas Indonesia, Depok-Indonesia
}

*Korespondensi: Rohayati | STIKes Mitra Keluarga | athearobiansyah@gmail.com

\begin{abstract}
Abstrak
Pendahuluan: Peningkatan prevalensi obesitas yang terus meningkat membutuhkan penanganan komprehensif dengan pendekatan multisektor. Peran keluarga sebagai caregiver utama sangat penting dalam penanganan obesitas. Tujuan penelitian adalah mengetahui persepsi dan pengalaman keluarga dalam merawat anggota keluarga dengan obesitas.

Metode: Penelitian ini menggunakan pendekatan kualitatif dengan desain fenomenologi deskriptif. Partisipan berjumlah 7 orang yang diperoleh secara purposive sampling.

Hasil: Dua tema yang dihasilkan yaitu dampak fisik dan psikososial yang dipersepsikan keluarga serta pengetahuan keluarga tentang kelebihan berat badan.

Kesimpulan: Perawat diharapkan mengajarkan penilaian status berat badan yang benar dan cara menghadapi dampak fisik serta psikologis yang mungkin terjadi pada keluarga dengan meningkatkan mekanisme koping.

Kata Kunci: Caregiver, Dampak fisik, Dampak psikologis, Obesitas, Pengetahuan
\end{abstract}

\section{Diterima 8 September 2019; Accepted 30 Desember 2019}

\section{PENDAHULUAN}

Obesitas termasuk salah satu "kondisi kronik" (Bray, Kim, Wilding \& World Obesity Federation, 2017). Sugondo (2014) mendefinisikan obesitas sebagai penumpukkan lemak yang abnormal maupun berlebihan yang dapat mengganggu kesehatan.

Prevalensi obesitas di seluruh dunia meningkat $47.1 \%$ untuk kategori usia di bawah 20 tahun dan $27.5 \%$ untuk usia dewasa di seluruh dunia ( $\mathrm{Ng}$ et all, 2014). Kelompok usia dengan prevalensi obesitas tertinggi di Indonesia adalah usia sekolah $8 \%$ dan usia dewasa mencapai $8 \%$. Selain itu, sekitar $26.6 \%$ penduduk usia dewasa menderita obesitas sentral (Badan Penelitian dan Pengembangan Kesehatan Kemenkes RI, 2013).

Prevalensi obesitas tertinggi di Provinsi Jawa Barat dialami kelompok usia dewasa sebesar $15.2 \%$. Secara umum, angka tersebut hampir dua kali lipat lebih tinggi dari prevalensi Indonesia. Meskipun begitu, angka obesitas sentral di Jawa Barat mencapai 26.4\% lebih rendah 0.2\% dari prevalensi nasional (Badan Penelitian dan Pengembangan Kesehatan Kemenkes RI, 2013). Prevalensi obesitas di Kota Depok cukup tinggi dibuktikan dengan $26.6 \%$ penduduk laki-laki dan $32.9 \%$ wanita mengalami obesitas sentral pada tahun 2013.

Keluarga merupakan sistem yang paling kecil yang terkena dampak akibat obesitas. Dampak yang dirasakan oleh keluarga akibat obesitas adalah meningkatnya biaya yang harus disediakan untuk pengobatan dan perawatan obesitas serta penyakit yang menyertainya. Wulansari, Martianto dan Baliwati (2016) memaparkan jumlah biaya perawatan kesehatan pada orang dewasa obesitas mencapai Rp 56.487 miliar/tahun.

Oleh karena itu, pelibatan keluarga dalam menangani obesitas merupakan hal yang penting. Friedman, Bowden, Jones (2014) mengemukakan salah satu fungsi keluarga adalah pemberi perawatan kesehatan dengan pemenuhan nutrisi keluarga. Pemenuhan kebutuhan nutrisi keluarga dapat dilakukan melalui pemenuhan gizi seimbang. Penelitian Hariyadi, Damanik dan Ekayanti (2010) menunjukkan bahwa 52.6\% responden masih belum menerapkan pesan umum gizi seimbang. Penelitian kualitatif yang dilakukan oleh Marlissa, Pandelaki dan Ratag (2015) kepada orang tua yang memiliki anak dengan kelebihan berat badan melalui wawancara diperoleh hasil bahwa pengetahuan partisipan masih kurang dan sikap positif partisipan masih kurang.

Penelitian kuantitatif tentang peran keluarga dalam memenuhi kebutuhan nutrisi keluarga menunjukkan 
bahwa terdapat hubungan antara memasak makan malam di rumah dengan peningkatan intake makanan rendah gula. Peneliti menjelaskan konsumsi makanan cepat saji satu minggu sekali erat kaitannya dengan meningkatnya prevalensi overweight/ obesitas (Taillie \& Poti, 2017).

Pelaksanaan fungsi pemenuhan nutrisi keluarga masih cenderung rendah sehingga prevalensi obesitas terus meningkat. Pengetahuan, persepsi serta pengalaman keluarga sangat penting untuk merumuskan program pencegahan obesitas dengan melibatkan peran serta aktif keluarga. Tujuan penelitian ini untuk menggali persepsi dan pengalaman keluarga dalam merawat anggota keluarga dengan obesitas.

\section{METODE}

Penelitian ini menggunakan pendekatan kualitatif dengan desain fenomenologi deskriptif. Kriteria inklusi partisipan adalah memiliki anggota keluarga dengan kegemukan tetapi tidak memiliki penyakit kronis serta bersedia menjadi partisipan. Jumlah partisipan didalam penelitian ini terdiri dari 7 (tujuh) orang pelaku rawat (caregiver) dengan usia termuda 29 tahun dan usia tertua 60 tahun. Teknik penentuan partisipan menggunakan teknik purfosive sampling.

Penelitian ini telah lolos uji etik dari Komite Etik Penelitian, Fakultas Keperawatan Universitas Indonesia dengan nomor 108/UN2.F12.D/HKP.02.04/2017. Peneliti melakukan wawancara setelah partisipan memperoleh penjelasan terkait penelitian dan menyetujui berpartisipasi sebagai informan dengan mengisi lembar informed consent. Pengumpulan data dilakukan melalui wawancara mendalam dan observasi lapangan. Pengambilan data penelitian dilakukan periode Mei-Juni 2017. Lokasi wawancara dilakukan di wilayah administratif kota Depok, Jawa Barat. Hasil wawancara dibuat ke dalam verbatim. Verbatim akan dianalisis dengan menggunakan tahapan analisis menurut Colaizzi (Shosha, 2012).

\section{HASIL}

\section{Karakteristik Partisipan}

Partisipan berjumlah 7 orang dengan rentang usia antara 29 tahun sampai 60 tahun, pendidikan terendah SD dan tertinggi sarjana, jumlah anggota keluarga yang mengalami kegemukan 1 sampai tiga orang di dalam satu, lima partisipan tidak bekerja atau ibu rumah tangga sedangkan dua partisipan bekerja sebagai karyawan dan buruh.

\section{Analisis Tema}

\section{Tema 1 Dampak fisik dan psikososial yang dipersepsikan keluarga}

Hasil penelitian ini menguraikan respon partisipan sebagai bentuk reaksi terhadap stimulus obesitas yang dialami keluarga. Respon yang dirasakan keluarga diuraikan dalam tema dampak fisik dan psikososial yang dipersepsikan keluarga.

Keluhan fisik dapat dilihat dari ungkapan partisipan berikut ini:

“...Gampang cape. kayak kita kan gemuk sendiri gampang cape, jalan sedikit cape,.....”

“...aduh capek, gitu loh kayak lelah gitu capek ..” (P2)

“...naik tangga ya paling engap doang sih, capek kan, turun naik turun naik...” P5)

“..kalau capek gitu selalu merintih kesakitan...(P2)

“...dengkul dua-duanya nih ya sakit” (P5)

Cape dan rasa sakit yang dialami mengakibatkan terjadinya penyesuaian aktivitas. Berikut kutipannya:

“...ngga mau ikutan temennya lari-lari.._kalau ditempat ngaji, udah duduk aja, diem,.” (P1)

“...Makanya saya sekarang sholat juga gak bisa berdiri, duduk, karena ini uda gak bisa ditekuk nih kaki..dua-duanya udah sakit...” (P5)

Kutipan berikut menggambarkan kondisi partisipan yang kesusahan mencari ukuran baju yang sesuai dengan ukuran badan:

“...kalau gemuk nyari baju susah, nyari celana susah...

“...nyari baju kemana-mana ngga dapet saya.. " (PO)

Selain mengungkapkan tentang keluhan di atas, partisipan juga menyampaikan pendapat tentang ukuran berat badan ideal berikut ini: 
“..orang tua saya ngomong kok sekarang gemuk banget...”(P1)

“........ kayaknya agak gemukan...”(P2)

“.temannya kan pantaran seumuran badannya yang ya standarlah..dia kok gemuk sendiri..” (P6)

"Usianya segini harusnya beratnya segini, segini gitu loh...” (P2)

Partisipan menggambarkan julukan yang diterima anggota keluarganya akibat obesitas seperti terlihat pada kutipan di bawah ini:

“...manggil kadang gendut...cadut...cadut (P1)

“...dipanggil gendutlah....” (P2)

“..ngatain doang gitu... kayak yang diteve ada yang gemuk itu kan, misalnya namanya yang gemuk itu kan, misalnya namanya ceu ida...dipanggil-panggil ceu ida... (P6)

Kutipan di bawah ini menggambarkan respon partisipan terhadap julukan tersebut:

“..kesel...tapi emang begitu adanya..”(P1)

“...ada rasa sakit hati ..." (P5)

“....balik ngatain sama orang yang ngata-ngatainnya...” (P6)

Partisipan menanggapi obesitas dengan perasaan yang berbeda-beda seperti kutipan berikut ini:

“...Tanggapannya paling bingung..” (P1)

“..Wajar aja, jajannya cukup makannya cukup..” (P3)

“...saya merasa masih nyaman dengan kondisi mereka...” (P7)

“...Kadang pernah sih takut gitu....” (P4)

"Takutnya ada apa-apa atau apa penyakit atau apa gitu, kadang katanya kalau gemuk juga kurang sehat... (P6)

Tema 2 Pengetahuan keluarga tentang Obesitas

Hasil wawancara menunjukkan pengetahuan keluarga tentang penyebab dan ukuran berat badan ideal.Berikut kutipannya:

“..Ya itu mie, sama daging-daging kayak burger gitu, ya makanan pokoknya makanan berlemak deh " (Pl)

“...lama-lama kok naik jadi 102, wah ini, karena makan malam nih...”(P5)

Kelebihan hormon dapat memicu terjadinya peningkatan berat badan menurut partisipan.

“...karena udah ngelebihin, hormonnya udah terlalu banyak gitu...” (P2)

Konsumsi susu juga dapat menyebabkan obesitas, berikut kutipannya:

“.........Kelebihan susu........” (P1)

“...susu formula... "(P4)

“...kalo anak yang susu formula...larinya kebadan katanya gemuk gitu....” (P7)

Penyebab selanjutnya yang diungkapkan partisipan adalah keturunan.

“.... udah keturunan gemuk... " (P5)

“..dari keturunannya dari saya juga gede-gede..(P6)

“...faktor keturunan..kayaknya dari postur ikut ayah (P7)

Kutipan di bawah ini menunjukkan ungkapan standar berat badan yang disampaikan oleh partisipan:

"belum ngerti apa gimana itu yang gemuk, gimana yang besar, standar sama umurnya ngga tau....."(PI)

"Belumnya itu... dari porsi berat badannya.....”(P2)

\section{PEMBAHASAN}

Tema 1 Dampak Fisik dan Psikososial yang dipersepsikan keluarga

Dampak fisik dan psikologis yang dipersepsikan diuraikan berdasarkan pengalaman partisipan terkait 
keluhan yang dialami keluarga. Keluhan fisik yang teridentifikasi antara lain cape atau mudah lelah, sakit dan kesulitan mencari ukuran baju. Hasil penelitian ini sesuai dengan hasil penelitian Brian (2011) yang mengungkapkan bahwa partisipan sering mengeluhkan nafas pendek dan kelelahan.

Cape atau kelelahan dialami partisipan merupakan bentuk adaptasi anatomi dan fisiologi tubuh terhadap peningkatan berat badan. Seseorang yang mengalami obesitas cenderung mengalami nafas pendek disebabkan oleh perubahan sistem kardiovaskuler. Bobot tubuh yang besar akan berimbas pada kerja jantung. Jantung akan bekerja lebih keras untuk memenuhi oksigenasi jaringan di seluruh tubuh. Kompensasi yang muncul akibat permintaan ini adalah peningkatan denyut jantung yang berakibat pada peningkatan volume dan sirkulasi darah dengan cara meningkatkan frekuensi nafas dan denyut nadi (Mehta, 2015).

Dill et al., (2016) menjelaskan bahwa obesitas mengakibatkan gangguan volume dan kapasitas paru pada anak-anak dan remaja. Peningkatan jaringan adiposa pada area dada dan abdomen mengakibatkan peningkatan tekanan intraabdominal. Hal ini berdampak pada penurunan compliance paru dan pergerakan dinding dada.

Hasil penelitian Littleton dan Tulaimat (2017) kepada 118 pasien menunjukkan bahwa terjadi penurunan level oksigen seiring dengan peningkatan IMT. Hal ini semakin memperberat kondisi kelelahan yang dirasakan oleh partisipan obesitas.

Kelelahan yang muncul bukan hanya semata-mata akibat perubahan sistem kardiovaskuler dan respirasi, tetapi juga disebabkan oleh perubahan sistem muskuloskeletal. Bollinger (2017) menjelaskan bahwa terjadi akumulasi lemak pada jaringan otot dan serat otot mengakibatkan penurunan fungsi otot yang berakibat pada munculnya respon mudah mengalami kelelahan.

Studi lain yang dilakukan oleh Barat et al. (2016) kepada anak-anak obesitas non diabetes untuk melihat kelelahan menunjukkan bahwa tingkat kelelahan dipengaruhi oleh tingginya IMT dan resistensi insulin. Kelelahan yang terjadi dapat menyebabkan rendahnya konsentrasi.

Penurunan fungsi kardiovaskuler, respirasi serta muskuloskeletal yang memicu kelelahan mengakibatkan tubuh melakukan adaptasi fisik terhadap kelelahan dalam bentuk mengurangi bentuk aktivitas salah satunya adalah jenis permainan pada anak. Sedangkan pada remaja dan orang dewasa penurunan kemampuan fisik dapat dilihat dari ketidakmampuan melakukan aktivitas sehari-hari secara optimal. Kondisi ini sesuai dengan hasil penelitian Forhan, Law, Vrkljan, dan Taylor (2010) dan Brian (2011) bahwa obesita mengakibatkan keterbatasan untuk melakukan aktivitas sehari-hari seperti olahraga, nafas pendek dan kelelahan.

Dampak yang dirasakan selanjutnya oleh keluarga yang mengalami obesitas dalam penelitian ini adalah kesulitan mencari ukuran baju yang pas. Hal ini sesuai dengan hasil penelitian Brian (2011) yang menyatakan bahwa partisipan mengungkapkan kesulitan menemukan pakaian dan sepatu yang sesuai.

Dampak fisik yang ditemukan pada keluarga selanjutnya adalah penilaian ukuran tubuh yang dipersepsikan. Hal ini berbeda dengan penelitian sebelumnya. Pada penelitian sebelumnya, partisipan adalah orang yang mengalami obesitas. Perbedaan ini disebabkan oleh karakteristik partisipan di dalam penelitian ini. Partisipan di dalam penelitian ini adalah pelaku rawat. Oleh karena itu, situasi dari lingkungan merupakan salah satu hal yang akan mempengaruhi persepsi partisipan termasuk pendapat, dan situasi dari lingkungan tentang berat badan keluarganya.

Obesitas tidak saja berakibat terhadap penurunan fungsional sistem tubuh, tetapi juga memiliki dampak terhadap kondisi psikologis seseorang. Tindakan yang diterima dari lingkungan yang berdampak pada kondisi psikologis orang dengan Obesitas pada penelitian ini berbentuk labelling. Labelling yang diterima sesuai dengan penelitian Brian (2011) dan Puhl dan Heuer (2009).

Seseorang yang mengalami obesitas dapat menerima atribut negatif yang tergambar dalam respon emosional dalam penelitian Sikorski, et al (2012). Atribut obesitas sebagai hasil kontrol internal seseorang merupakan dasar terjadinya stigma terhadap berat badan (Puhl \& Heuer, 2009). Brian (2011) menyatakan bahwa partisipan yang mengalami obesitas sering menerima bullying verbal dalam bentuk panggilan yang identik dengan berat badannya. Puhl dan Heuer (2009) selanjutnya memberikan contoh stigma yang diperoleh pada orang dewasa di tempat kerja mencakup sasaran humor dan komentar peyoratif baik dari teman maupun atasan.

Sumber bullying berasal dari teman sebaya, guru, media sosial maupun lingkungan masyarakat (Brian, 2011). Akan tetapi pada penelitian ini bulying verbal yang diterima keluarga dalam penelitian ini berasal 
dari teman, tetangga dan keluarga.

Labelling mengakibatkan seseorang berespon dan membatasi aktivitas dari lingkungan sekitarnya. Situasi diatas sesuai dengan aspek kerentanan yang diungkapkan oleh Stanhope dan Lancaster (2016) yaitu disfrenchisement. Aspek ini menunjukkan bahwa seseorang yang berada dalam kondisi rentan merasakan dirinya terpisah atau berbeda dari lingkungan sekitarnya. Aspek tersebut didukung oleh hasil penelitian dari Brian (2011) yang menyatakan bahwa remaja yang mengalami obesitas merasa dirinya berbeda dengan orang lain dari sisi penampilan fisik.

Reaksi keluarga dalam merespon labeling bermacam-macam. Sebagian mengungkapkan rasa kesal, sakit hati tapi ada juga yang tidak terlalu mempedulikan julukan yang diterimanya. Respon ini mengalami perbedaan sesuai usia anggota keluarga yang mengalami obesitas. Anak-anak cenderung tidak terlalu mempedulikan labeling yang diterimanya. Akan tetapi orang dewasa menyikapi labelling dengan cara yang berbeda. Mereka mengungkapkan keluhan baik kesal maupun sakit hati.

Perbedaan reaksi ini salah satunya dapat disebabkan oleh konsep diri yang ada pada orang tersebut. Griffiths, Dezateux, dan Hill (2011) dan Scott et all (2008) menjelaskan bahwa terdapat hubungan antara obesitas dan gangguan psikologis pada remaja. Oleh karena itu, hal-hal yang bersifat mengancam pada orang obesitas dapat memiliki dampak terhadap gambaran diri dan konsep diri. Hasil penelitian Scott et al (2008) menunjukkan bahwa terdapat hubungan antara obesitas dengan gangguan emosional pada wanita.

Pandangan tentang konsep diri menggambarkan bagaimana seseorang memandang dirinya secara fisik, sosial dan spiritual. Nilai-nilai yang ada di masyarakat sangat mempengaruhi perkembangan konsep diri seseorang (Scott et al, 2008). Konsep diri berkembang sesuai dengan timbal balik atas respon sosial yang diterima dan kemampuan seseorang untuk menangkap ide dan keberhasilan secara personal (Serassuel Junior, Cavazzotto, Paludo, Zambrin, \& Simões, 2015). Gibson et al. (2008) menjelaskan bahwa semakin tinggi IMT semakin rendah harga diri yang dimiliki.

Korban bullying verbal dapat mengalami gangguan psikososial. Gangguan psikososial yang dialami partisipan dalam penelitian ini diantaranya adalah harga diri rendah. Hal tersebut sesuai dengan hasil penelitian Robertson, Murphy dan Johnson (2016). Bookhout (2016) menyatakan akibat psikologis lainnya adalah menarik diri dari lingkungan sosial.

\section{Tema 2 Pengetahuan keluarga tentang Obesitas}

Partisipan dalam penelitian ini menyampaikan makanan berlemak sebagai salah satu penyebab obesitas. Hasil penelitian ini sesuai dengan penelitian Aggarwal, Bhatia, Singh dan Sobti (2008) yang menyatakan bahwa konsumsi makanan tinggi kalori merupakan salah satu penyebab obesitas. Kemudahan akses terhadap konsumsi makanan cepat saji mengakibatkan tingginya frekuensi mengkonsumsi makanan tinggi lemak. Dalle Molle et al (2017) menyampaikan bahwa konsumsi makanan cepat saji dipengaruhi oleh praktek pemberian makan di keluarga baik dalam bentuk reward maupun kebiasaan bepergian pada akhir pekan untuk makan di restoran cepat saji.

Lingkungan atau teman sebaya mempengaruhi kses terhadap makanan cepat saji. Salah satu keluarga mengungkapkan bahwa usaha dietnya seringkali gagal karena ajakan teman untuk pergi ke restoran cepat saji. Hal ini sesuai dengan hasil penelitian bahwa konsumsi makanan dan jajanan sangat dipengaruhi oleh teman di lingkungannya (Wijaya, Ardiana, \& Kurniawati, 2014).

Penyebab obesitas berikutnya adalah kondisi hormon. Keluarga mengatakan hasil konsultasi dengan dokter menunjukkan bahwa kadar hormon tertentu pada anak tersebut melebihi ambang batas normal. Hal ini sesuai dengan hasil penelitian sebelumnya yang membuktikan bahwa obesitas pada usia anak-anak disebabkan oleh defisiensi leptin atau penyebab medis lain seperti hipotiroidisme, defisiensi hormon pertumbuhan (Reilly et al, 2005). Kondisi kelebihan hormon tersebut akan memicu sekresi adipositokin oleh jaringan adiposa. Efek selanjutnya akan memicu peningkatan kadar leptin. Leptin akan mengirimkan sinyal kepada hipotalamus yang mengatur perilaku pencarian makanan dan intake makanan. Oleh karena itu, seseorang yang mengalami kelebihan hormon dapat menunjukkan perilaku dan intake makanan melebihi porsi yang dianjurkan sesuai usianya.

Keturunan disampaikan keluarga sebagai penyebab obesitas berikutnya. Keluarga mengatakan terkadang saudara, orang tua, sepupu atau keluarga yang lain memiliki postur yang sama atau bahkan lebih besar. Penelitian yang dilakukan oleh Bottcher dan Kovacs (2015) menunjukkan bahwa sebesar 0.7 kasus obesitas disebabkan oleh keturunan. Penelitian lain yang dilakukan oleh Ranjani, Pradeepa dan Mohan 
(2014) menjelaskan bahwa obesitas pada orang tua merupakan prediktor kuat sebagai penyebab obesitas pada saat usia dewasa.

Partisipan mengungkapkan bahwa konsumsi susu formula yang berlebihan merupakan salah satu pemicu terjadinya obesitas. Hal tersebut sesuai dengan penelitian Sartika (2011) yang menyatakan bahwa salah satu faktor terjadinya obesitas pada anak usia 5-15 tahun adalah konsumsi protein yang berlebihan.

Penyebab obesitas yang terakhir diungkapkan partisipan adalah kebiasaan makan malam. Keluarga mengungkapkan bahwa kebiasaan makan malam menjelang waktu tidur kemungkinan mengakibatkan berat badannya terus meningkat. Hasil penelitian ini sesuai dengan hasil penelitian Karatzi, Moschonis, Choupi, Manios, (2017) yang menunjukkan bahwa pada anak-anak yang terbiasa mengkonsumsi makan malam antara jam 20.00-22.00 beresiko mengalami peningkatan indeks masa tubuh.

Partisipan yang terbiasa makan larut malam pada penelitian ini menyampaikan selalu melewatkan waktu sarapan. Studi lain menjelaskan bahwa melewatkan waktu sarapan beresiko memicu peningkatan indeks massa tubuh (Szajewska \& Ruszczyński, 2010).

Partisipan belum mengetahui cara menentukan status berat badan ideal berdasarkan hasil penimbangan. Hal ini sesuai dengan tema yang dihasilkan oleh Akhmadi (2011) dimana partisipan memiliki persepsi baik dengan mengungkapkan hasil pengamatan terhadap kondisi berat badan yang tidak seimbang dengan tinggi badan.

\section{KESIMPULAN}

Tema yang dihasilkan dalam penelitian ini merefleksikan cara pandang serta pengalaman partisipan dalam merawat anggota keluarga dengan obesitas. Dua tema tersebut adalah dampak fisik dan psikososial yang dipersepsikan keluarga serta pengetahuan keluarga tentang obesitas.

Perawat perlu mengajarkan kepada keluarga tentang menilai status berat badan yang benar, mengurangi penyebab terjadinya obesitas, menghadapi dampak fisik serta psikologis yang mungkin terjadi pada anggota keluarga yang mengalami obesitas dengan meningkatkan mekanisme koping yang konstruktif.

\section{REFERENSI}

Akhmadi. (2009). Pengalaman keluarga Merawat Anak Usia Sekolah dengan Obesitas yang. Bersekolah di Sekolah Dasar Kota Yogyakarta: Studi fenomenologi. diunduh dari lib.ui.ac.id/file?file=digital/201610/124138-Akhmadi.pdf

Aggarwal, T., Bhatia, R.C., Singh, D., Sobti, P.C., (2008). Prevalence of obesity and overweight in affluent adolescent from Ludhiana, Punjab. Indian Pediatr. 45: 500-502.

Badan Penelitian dan Pengembangan Kesehatan Depkes RI. (2013). Riset Kesehatan Dasar tahun 2013. Jakarta: Depkes RI.

Barat, P., Meiffred, M. C., Brossaud, J., Fuchs, D., Corcuff, J. B., Thibault, H., \& Capuron, L. (2016). Inflammatory, endocrine and metabolic correlates of fatigue in obese children. Psychoneuroendocrinology, 74, 158-163.

Bollinger, L. M. (2017). Potential contributions of skeletal muscle contractile dysfunction to altered biomechanics in obesity. Gait \& posture, 56, 100-107.

Böttcher, Y., \& Kovacs, P. (2015). Genetics of obesity in childhood and adolescence. Metabolic Syndrome and Obesity in Childhood and Adolescence, 19, 31-39.

Bookhout, M. K. (2015). The role of peer victimization in the relations between obesity, negative body cognitions, and negative psychosocial outcomes. University of Delaware.

Bray, G. A., Kim, K. K., Wilding, J. P. H., \& World Obesity Federation. (2017). Obesity: a chronic relapsing progressive disease process. A position statement of the World Obesity Federation. Obesity Reviews, 18(7), 715-723.

Brian, R. L. (2011). The Experiences of Living with Excess Weight as an Adolescent: Everyday Life and Healthcare Encounters. Retrieved from http://rave.ohiolink.edu/etdc/view?acc_num=kent1300370920

Dalle Molle, R., Fatemi, H., Dagher, A., Levitan, R. D., Silveira, P. P., \& Dubé, L. (2017). Gene and environment interaction: Is the differential susceptibility hypothesis relevant for obesity? Neuroscience \& Biobehavioral Reviews, 73, 326-339. http://doi.org/10.1016/j.neubiorev.2016.12.028

Dinas Kesehatan Kota Depok. (2016). Profil Kesehatan Kota Depok 2015. diunduh dari http://dinkes.depok.go.id/?page_id=23 
Forhan, M. a, Law, M. C., Vrkljan, B. H., \& Taylor, V. H. (2010). The experience of participation in everyday occupations for adults with obesity. Canadian Journal of Occupational Therapy. Revue Canadienne D'ergotherapie, 77(4), 210-218. http://doi.org/10.2182/cjot.2010.77.4.3

Friedman, M. M., Bowden, V. R., \& Jones, E. G. (2014). Buku Ajar Keoerawatan Keluarga (Riset, teori, dan praktik) Edisi 5. Jakarta : EGC.

Gibson, L. Y., Byrne, S. M., Blair, E., Davis, E. A., Jacoby, P., \& Zubrick, S. R. (2008). Clustering of psychosocial symptoms in overweight children. Australian and New Zealand Journal of Psychiatry, 42(2), 118-125.

Griffiths, L. J., Dezateux, C., \& Hill, A. (2011). Is obesity associated with emotional and behavioural problems in children? Findings from the Millennium Cohort Study. Pediatric Obesity, 6(2Part2).

Hariyadi, D., Damanik, M. R., \& Ekayanti, I. (2010). Analisis Hubungan Penerapan Pesan Gizi Seimbang Keluarga dan Perilaku Keluarga Sadar Gizi dengan Status Gizi Balita di Provinsi Kalimantan Barat. Jurnal Gizi dan Pangan, 5(1), 61-68.

Karatzi, K., Moschonis, G., Choupi, E., Manios, Y., \& Healthy Growth Study Group. (2017). Late-night overeating is associated with smaller breakfast, breakfast skipping, and obesity in children: The Healthy Growth Study. Nutrition, 33, 141-144.

Littleton, S. W., \& Tulaimat, A. (2017). The effects of obesity on lung volumes and oxygenation. Respiratory Medicine, 124, 15-20.

Marlissa, E. W., Pandelaki, A. J., \& Ratag, G. A. (2015). Perilaku orang tua dan keluarga terhadap obesitas pada anak kelas 5 SD di SDN 70 Manado. Jurnal Kedokteran Komunitas dan Tropik, 3(4).

Mehta, S. K. (2015). Waist circumference to height ratio in children and adolescents. Clinical pediatrics, 54(7), 652-658.

Ng, M., Fleming, T., Robinson, M., Thomson, B., Graetz, N., Margono, C., ... Gakidou, E. (2014). Global, regional, and national prevalence of overweight and obesity in children and adults during 1980-2013: a systematic analysis for the Global Burden of Disease Study 2013. The Lancet, 384(9945), 766-781. http://doi.org/10.1016/S0140-6736(14)60460-8.

Puhl, R. M., \& Heuer, C. A. (2009). The stigma of obesity: a review and update. Obesity, 17(5), 941-964.

Ranjani, H., Pradeepa, R., Mehreen, T. S., Anjana, R. M., Anand, K., Garg, R., \& Mohan, V. (2014). Determinants, consequences and prevention of childhood overweight and obesity: An Indian context. Indian journal of endocrinology and metabolism, 18(Suppl 1), S17.

Reilly, J. J., Armstrong, J., Dorosty, A. R., Emmett, P. M., Ness, A., Rogers, I., ... \& Sherriff, A. (2005). Early life risk factors for obesity in childhood: cohort study. Bmj, 330(7504), 1357.

Robertson, W., Murphy, M., \& Johnson, R. (2016). Evidence base for the prevention and management of child obesity. Paediatrics and Child Health, 26(5), 212-218.

Sartika, R.A.D., (2011). Faktor resiko obesitas pada anak usia 5-15 tahun di Indonesia. Makara Kesehatan. 15 (1):37-43. October, 10 2016. http:// journal.ui.ac.id/health/article/download/796/758.

Scott, K. M., Bruffaerts, R., Simon, G. E., Alonso, J., Angermeyer, M., de Girolamo, G., ... \& Kessler, R. C. (2008). Obesity and mental disorders in the general population: results from the world mental health surveys. International journal of obesity, 32(1), 192-200.

Serassuel Junior, H., Cavazzotto, T. G., Paludo, A. C., Zambrin, L. F., \& Simões, A. C. (2015). The impact of obesity on the perception of self-concept in children and adolescents. Revista Brasileira de Cineantropometria \& Desempenho Humano, 17(2), 165-174.

Shosha, G. (2012). Employment of Colaizzi'S Strategy in Descriptive Phenomenology: a Reflection of a Researcher. European Scientific Journal, 8(27), 31-43. http://doi.org/10.1093/cid/cir626

Sikorski, C., Riedel, C., Luppa, M., Schulze, B., Werner, P., König, H. H., \& Riedel-Heller, S. G. (2012). Perception of overweight and obesity from different angles: a qualitative study. Scandinavian Journal of Social Medicine, 40(3), 271-277.

Stanhope. M., Lancaster, J., (2016). Public health nursing: population centre health care in the community. 9th edition. St Lous: Mosby.

Sugondo, S. (2014). Obesitas. dalam buku ajar ilmu penyakit dalam edisi V . Aru, AB; Setiyohadi, B, Alwi, I; Simadibrata, M; Setiati, S (Ed.) FK UI: Jakarta.

Szajewska, H., \& Ruszczyński, M. (2010). Systematic review demonstrating that breakfast consumption influences body weight outcomes in children and adolescents in Europe. Critical reviews in food 
science and nutrition, 50(2), 113-119.

Taillie, L. S., \& Poti, J. M. (2017). Associations of Cooking With Dietary Intake and Obesity Among Supplemental Nutrition Assistance Program Participants. American Journal of Preventive Medicine, 52(2), S151-S160. http://doi.org/10.1016/j.amepre.2016.08.021

Wijaya, D., Ardiana, A., \& Kurniawati, D. (2014). Laporan akhir ipteks bagi masyarakat (IbM) IbM Kelompok Usaha Kesehatan Sekolah ( UKS ) Tingkat Sekolah Dasar.

Wulansari, A., Martianto, D., \& Baliwati, Y. F. (2016). Estimasi kerugian ekonomi akibat obesitas pada orang dewasa di Indonesia. Jurnal Gizi dan Pangan, 11(2), 159-168. 